\title{
Ability of Organic and Inorganic Bedding Materials to Promote Growth of Environmental Bacteria
}

\author{
S. Godden, ${ }^{\star 1}$ R. Bey,† K. Lorch,‡ R. Farnsworth, ${ }^{\star}$ and P. Rapnicki ${ }^{\star}$ \\ *Department of Veterinary Population Medicine, and \\ †Department of Veterinary and Biological Sciences, University of Minnesota, St. Paul 55108 \\ †Lewiston Veterinary Services, Lewiston, MN 55952
}

\begin{abstract}
The major objective of this study was to contrast the ability of 4 commonly utilized bedding materials to promote growth of environmental bacteria under controlled conditions. A second objective was to describe the relationship between bacterial growth and specific biochemical or nutritional properties of these bedding materials. Unused samples of clean sand (CS; $n=20$ ), recycled sand (RS; $n=21$ ), digested manure solids (DS; $\mathrm{n}=15$ ), and shavings ( $\mathrm{SH} ; \mathrm{n}=15$ ) were collected from bedding storage areas on 49 commercial Minnesota and Wisconsin dairy farms. Sterilized bedding samples were inoculated with Klebsiella pneumoniae and Enterococcus faecium then incubated, in triplicate, for 72 $\mathrm{h}$ at $37^{\circ} \mathrm{C}$. Subsamples were collected after $0,24,48$, and $72 \mathrm{~h}$ of incubation for culture and enumeration of bacteria. Subsamples of bedding were also tested for $\mathrm{pH}$, total $\mathrm{C}$ content (\%), and total $\mathrm{N}$ content (\%). If bacterial growth occurred, peak levels were typically achieved within $24 \mathrm{~h}$. Digested manure solids promoted the greatest amounts of growth of $K$. pneumoniae, followed by RS and then $\mathrm{SH}$, whereas CS promoted the least. There would seem to be a tradeoff in selecting $\mathrm{SH}$ as a bedding material, because it supported moderate growth of $K$. pneumoniae but caused a rapid decline in the numbers of $E$. faecium. However, RS, CS, and DS each only supported relatively small amounts of growth of $E$. faecium, so the benefit of $\mathrm{SH}$ relative to other bedding materials is limited. High bedding $\mathrm{pH}$ may partially explain why some bedding materials supported growth of E. faecium (e.g., DS and RS). Both high bedding $\mathrm{pH}$ (e.g., as for DS or RS) and high total $\mathrm{C}(\%)$ content (e.g., as for DS and SH) may partially explain why some bedding materials supported growth of $K$. pneumoniae.
\end{abstract}

Key words: bedding, environmental mastitis, bacteria

Received June 4, 2007.

Accepted September 21, 2007.

${ }^{1}$ Corresponding author: godde002@umn.edu

\section{INTRODUCTION}

Despite many advances, mastitis remains the most costly infectious disease affecting dairy cattle (Fetrow et al., 2002). Environmental mastitis pathogens, including coliform bacteria and environmental streptococci species (Streptococcus dysgalactiae, Streptococcus uberis, and Enterococcus spp.), are responsible for a significant portion of mastitis infections (Eberhart, 1984; Johnson, 2001; Fetrow et al., 2002). Adopting management practices that reduce bacterial exposure to the teat end during intermilking periods should help to reduce the incidence of IMI. Bedding materials can be an important source of bacterial exposure for teat ends (Eckes et al., 2001). Studies have reported that the bacteria types and counts found in bedding materials have a positive correlation with the bacteria types and counts present on the teat end (Rendos et al., 1975; Hogan et al., 1989, 1990; Hogan and Smith, 1997; Zdanowicz et al., 2004). As such, in addition to availability, cost, cow comfort, and manure handling, producers should also consider the ability of a bedding material to promote growth of environmental mastitis pathogens when selecting a bedding material.

To sustain or promote bacterial growth, bedding must first be inoculated with bacteria. This dose of inoculating bacterial could already be present in the bedding material before it is put into the stall (e.g., pathogen recycling in digested manure solids or recycled sand) or could result from defecation or by tracking manure into the back of the stall. Once inoculated, factors that can influence the ability of bacteria to multiply in bedding include ambient temperature, moisture/humidity, bedding management (e.g., frequent removal and replacement of contaminated bedding), and presence of sufficient required nutrients. These nutrients could be introduced through contamination of the bedding with organic materials such as feces or milk (Dodd et al., 1984). Alternately, the bedding material itself may already have inherent physical, biochemical, or nutritional properties that could sustain or promote bacterial growth. 
Bedding materials traditionally used by Northeast and Midwest US dairies have included shavings (SH), clean sand (CS), and chopped straw. However, alternative bedding materials receiving increased attention in recent years include recycled (mechanically separated) sand (RS) and, coinciding with the relatively recent introduction of on-farm anaerobic manure digestion systems, separated postdigested manure solids (DS). These various bedding materials could vary widely in their physical and biochemical properties, which could dramatically affect their inherent ability to promote mastitis pathogen growth. Studies have reported that organic bedding materials (wood shavings, sunflower hulls, straw) tend to contain higher levels of environmental bacteria than inorganic materials (e.g., sand; Hogan and Smith, 1987; Eckes et al., 2001; Bey and Reneau, 2002). Most of these studies were conducted with used bedding samples collected from stalls on dairy farms. One early study compared the ability of hardwood chips, recycled dried manure, chopped newspaper, softwood sawdust, and chopped straw to support growth of environmental pathogens, independent of the presence of feces, urine, or other contamination (Zehner et al., 1986). However, relatively few studies have reported on bacteria levels in more recently adopted bedding materials such as RS or DS (Kristula et al., 2005, Gooch et al., 2006). Also, studies are lacking that allow producers or consultants to directly compare the bacterial growth-promoting potential of traditional vs. relatively new alternative bedding materials such as digested manure solids. The major objective of this study was to directly contrast the ability of 4 bedding materials, CS, RS, SH, and DS, to promote growth of environmental bacteria under controlled conditions. A second objective was to describe the relationship between bacterial growth and specific biochemical or nutritional properties of these bedding materials, including $\mathrm{pH}$, total $\mathrm{N}$ content, and total $\mathrm{C}$ content.

\section{MATERIALS AND METHODS}

\section{On-Farm Bedding Sample Collection}

The goal was to collect at least 15 unique unused bedding samples representing each of the 4 bedding materials under study. These sample size estimates were calculated from bedding culture results from an earlier pilot study (R. Bey and S. Godden; unpublished data), which compared growth of Klebsiella pneumoniae and Enterococcus faecium in SH, CS, and RS. Commercial Minnesota and Wisconsin dairies sampled included 15 herds using DS, 14 herds using $\mathrm{SH}$, and 20 herds using RS. For herds using sand bedding, both a CS sample (never been used) and a RS sample were collected. None of the study herds were using a commercial bedding conditioner at the time of sample collection. The study technician wore clean gloves to collect an approximate $500-\mathrm{g}$ sample from the bedding storage area (e.g., bedding storage pad or commodity shed) into a clean sterile plastic bag. Bedding samples were placed in a cooler with ice packs and transported directly to the Laboratory for Udder Health, University of Minnesota (St. Paul).

\section{Laboratory Procedures}

Bedding Sample Preparation. Three 25-cc subsamples from each original bedding sample were sterilized using ethylene oxide. Sterile distilled water was then aseptically added to each bedding subsample to achieve a 1:5 (vol/vol) bedding:water suspension.

Bacteria Preparation and Inoculation. Enterococcus faecium and $K$. pneumoniae were isolated, using routine culture methods, from clinical mastitis milk samples received at the University of Minnesota Laboratory for Udder Health. Well-isolated colonies were restreaked and incubated. After incubation at $37^{\circ} \mathrm{C}$ for $18 \mathrm{~h}$, the identity of the isolates was verified using the API 20E (gram-negative) or the API 20 Strep Lancefield group D-positive (bioMerieux Vitek Inc., Hazelwood, MO). Polymerase chain reaction was also used to confirm the identity of the $E$. faecium isolate. Isolated organisms of each type were then streaked for isolation on blood agar plates and incubated at $37^{\circ} \mathrm{C}$ for $24 \mathrm{~h}$. Pure cultures of these bacteria were then added to sterile distilled water to produce bacterial suspensions equal in turbidity to a $0.5 \mathrm{McF}$ arland standard (approximately $10^{8} \mathrm{cfu} / \mathrm{mL}$ ). One milliliter of $K$. pneumoniae suspension was then added to $100 \mathrm{~mL}$ of the beddingwater suspension for each bedding subsample to create a final inoculation of approximately $10^{6} \mathrm{cfu} / \mathrm{mL}$. This inoculation step was completed in triplicate. The final colony-forming units per milliliter counts achieved were determined at the time of bedding inoculation (time 0 sample). This inoculation procedure was repeated with a second set of subsamples using the $E$. faecium bacterial suspension.

Bacterial Culture and Enumeration. Samples from the bacteria-bedding suspensions were collected on the day of inoculation $(0 \mathrm{~h})$ and after 24,48 , and 72 $\mathrm{h}$ of incubation at $37^{\circ} \mathrm{C}$. The bacteria-bedding samples were mixed and then allowed to stand for $10 \mathrm{~min}$, after which a $200-\mu \mathrm{L}$ sample was aseptically removed and placed in sterile brain heart infusion broth. Serial 10fold dilutions of these samples were made in brain heart infusion broth. Sample dilutions were plated in triplicate on colistin naladixic acid media (BBL, Sparks, MD) for isolation and enumeration of $E$. faecium and on MacConkey media (BBL, Sparks, MD) for isolation and 
enumeration of $K$. pneumoniae. Two hundred microliters of each sample dilution was placed on each plate using Pipetman pipetters (Rainin Instrument LLC, Oakland, CA) and spread evenly on the surface of the agar with sterile glass spreading rods. Colony counts were determined for each plate after $24 \mathrm{~h}$ of incubation at $37^{\circ} \mathrm{C}$. Only those plates having 30 to 300 discrete colonies were counted and used in the analysis. The colony counts from each of 3 replicate samples were averaged to calculate the mean number of colony-forming units per milliliter (cfu/mL) of $E$. faecium and $K$. pneumoniae for each bedding sample.

Biochemical Testing. One $\mathrm{pH}$ reading of each bedding sample was taken by adding $5 \mathrm{~g}$ of sterile bedding material into $50 \mathrm{~mL}$ of sterile distilled water, mixing well, and allowing the bedding:water mixture to stand for 30 min with occasional mixing. The $\mathrm{pH}$ was determined using a Corning $320 \mathrm{pH}$ meter (Corning Inc., Corning, NY). Total $\mathrm{C}$ and $\mathrm{N}$ content of bedding samples was measured using a Skalar Primacs ${ }^{\text {sc }}$ TOC Analyzer (Skalar Inc., Norcross, GA) and a Leco FP528 Nitrogen Analyzer (Leco Corp., St. Joseph, MI), respectively.

Data Management. Data were assembled into a database file (Microsoft Excel, Microsoft Corp., Redmond, WA) included the following information for each bedding sample: sample number, farm of origin, bedding type (CS, RS, DS, or $\mathrm{SH}), \mathrm{pH}$, total $\mathrm{N}$ content (\%), total $\mathrm{C}$ content $(\mathrm{C})$, and for each incubation period (0, 24,48 , or $72 \mathrm{~h}$ ), the average bacteria count ( $\mathrm{cfu} / \mathrm{mL}$ ) for both $E$. faecium and $K$. pneumoniae. Because the bacteria count data were nonnormally distributed, these data were transformed to a $\log _{10}(\mathrm{cfu} / \mathrm{mL})$ value for each sample. Bacterial growth [difflog $10(\mathrm{cfu} / \mathrm{mL})$ ] was calculated as the difference between the $\log _{10}(\mathrm{cfu} /$ $\mathrm{mL}$ ) after incubation at the 24-, 48-, and 72-h sampling points and the $\log _{10}(\mathrm{cfu} / \mathrm{mL})$ at the time of origin (0).

\section{Statistical Analysis}

Descriptive Statistics. The mean, standard deviation, and range for $\mathrm{pH}$, total $\mathrm{C}(\%)$, and total $\mathrm{N}(\%)$ values were calculated for each bedding type (CS, RS, $\mathrm{DS}, \mathrm{SH})$. The absolute bacteria count $\left[\log _{10}(\mathrm{cfu} / \mathrm{mL})\right]$ was reported at the 0-, 24-, 48-, and 72-h sampling points, and the bacterial growth [difflog $10(\mathrm{cfu} / \mathrm{mL})]$ was reported for the 0 to 24-, 0 to 48-, and 0 to 72-h incubation periods for both $E$. faecium and $K$. pneumoniae.

Relationship Between Bedding Type and Bacterial Growth. Linear regression (PROC MIXED in SAS, version 9.1, SAS Institute Inc., Cary, NC) and contrast analysis were used to describe the relationship between the 2 dependent variables of interest (growth of $E$. faecium; growth of $K$. pneumoniae) and the explanatory variable of interest, bedding type (CS, RS, DS, SH).
Incubation period ( 0 to 24,0 to 48,0 to $72 \mathrm{~h}$ ) was also offered as a covariate into the model. Because a significant interaction was found to exist between bedding type and incubation period, data were stratified by incubation period for the final analysis. Inclusion of a variable describing herd as a random effect was initially explored but was ultimately excluded, because, although CS and RS samples were collected from the same herds of origin, the bedding samples themselves were considered to be independent of one another, having been delivered to the farm at very different times in the year and quite possibly from different sources. Also, in test models that included herd as a random effect variable, the statistical inferences did not change. Final significance was declared at $P<0.05$.

Relationship Between Biochemical and Nutritional Properties of Different Bedding Materials and Bacterial Growth. Univariate linear regression (PROC MIXED in SAS, version 9.1) was used to describe, at each sampling point $(24,48$, or $72 \mathrm{~h})$, the relationship between each of the 2 dependent variables of interest (growth of $E$. faecium; growth of $K$. pneumon$i a e$ ) and each of the following explanatory variables of interest: $\mathrm{pH}$, total $\mathrm{N}(\%)$, and total $\mathrm{C}(\%)$. Variables significant at $P<0.2$ were offered into the final multivariate model. All possible 2 -way interactions were explored between covariates. A backwards stepwise approach was then used to build a final multivariate model. As an additional step, bedding type (CS, RS, DS, $\mathrm{SH}$ ) was then forced into the final multivariate model to investigate whether associations identified between bacterial growth and bedding type were likely to be independent of, or associated with, these specific biochemical properties.

As a final step, the database was stratified by bedding type, and univariate linear regression (PROC MIXED in SAS, version 9.1) was used to describe if a relationship existed between bacterial growth $(E$. faecium or $K$. pneumoniae) and biochemical properties $[\mathrm{pH}$, total $\mathrm{N}(\%)$, total $\mathrm{C}(\%)]$ within each of the 4 bedding types. Final significance for all models was declared at $P<$ 0.05 .

\section{RESULTS}

\section{Descriptive Statistics}

The final data set included 20 CS samples from 19 farms, $21 \mathrm{RS}$ samples from 20 farms, 15 DS samples from 15 farms, and $15 \mathrm{SH}$ samples from 14 farms. For the one $\mathrm{SH}$ farm that was sampled twice, samples were collected at least 4 wk apart and so were considered to be independent. Descriptive statistics reporting the mean (SD, range) values for $\mathrm{pH}$, total $\mathrm{C}(\%)$, total $\mathrm{N}$ 
Table 1. Biochemical characteristics and bacterial growth observed in 4 bedding materials ${ }^{1}$

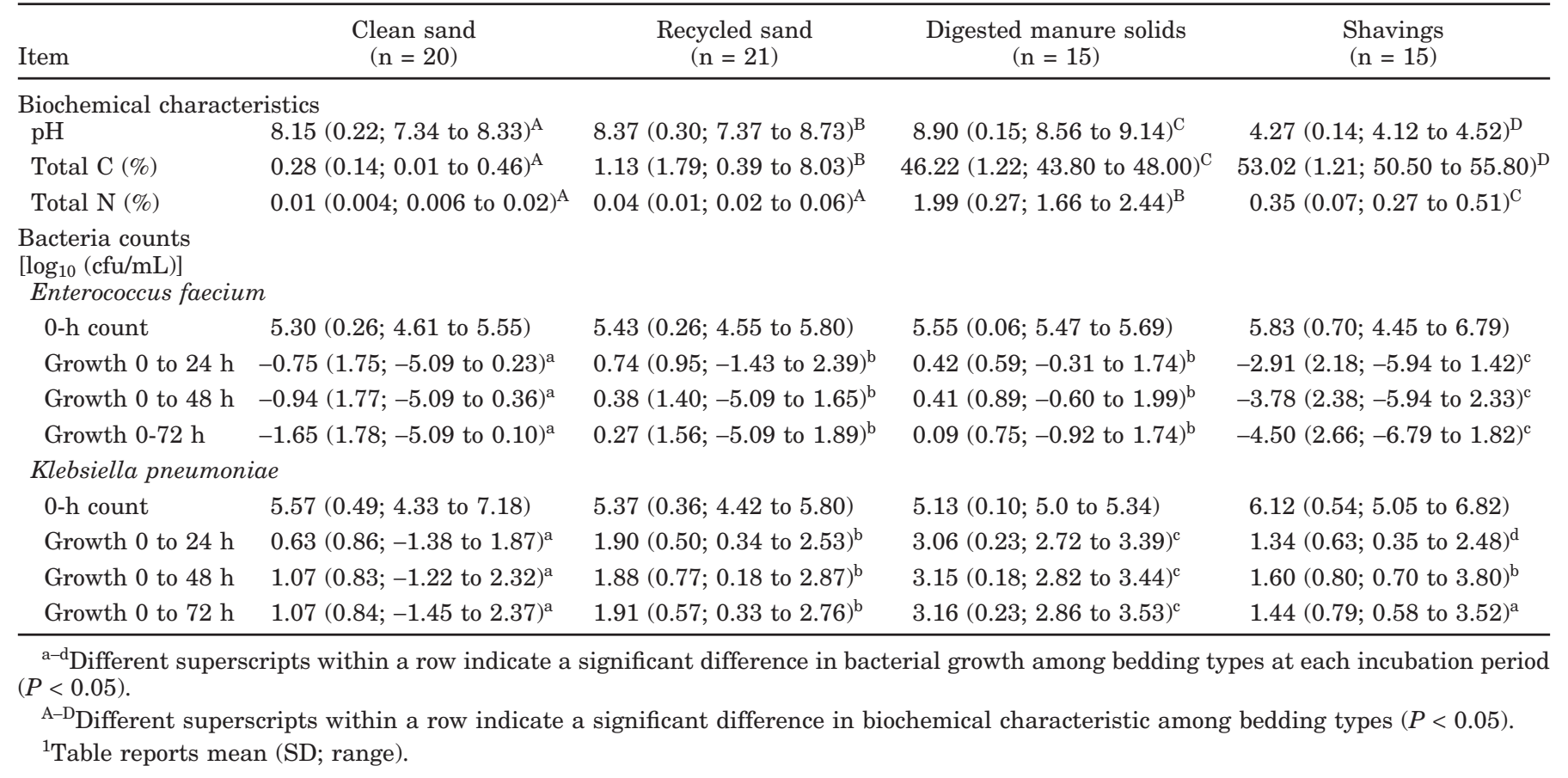

$(\%)$, bacteria counts at $0 \mathrm{~h}$, and bacterial growth after 24,48 , and $72 \mathrm{~h}$ of incubation are reported in Table 1.

When describing growth of $K$. pneumoniae within a specific bedding type over the 72-h incubation period, there were varying increases (growth) in $K$. pneumoniae counts observed within all 4 bedding types (Figure 1). For RS, DS, and SH, the bacteria completed the log phase of growth during the first $24 \mathrm{~h}$ and then entered the stationary phase of growth (no further increase or decrease) from 24 to 72 h. For CS, growth of $K$. pneumoniae went through the log phase of growth during the first $48 \mathrm{~h}$ and then entered the stationary phase of growth to $72 \mathrm{~h}$. It is expected that organisms would enter the stationary phase of growth due to a decrease in availability of necessary nutrients or altered environmental parameters (e.g., $\mathrm{pH}$ ).

When describing growth of $E$. faecium within a specific bedding material over the 72-h incubation period, there were decreases in numbers of $E$. faecium over the entire 72-h period for both CS and SH (death phase of growth; Figure 2). By comparison, for RS there was an increase in $E$. faecium numbers (log phase of growth) during the first $24 \mathrm{~h}$, followed by a plateau in numbers (stationary phase of growth) to $72 \mathrm{~h}$. There was no change in $E$. faecium numbers for DS over the entire 72-h incubation period (stationary growth phase).

Mean $\mathrm{pH}$ values were different among all 4 bedding types, ranging from lowest to highest as $\mathrm{SH}(4.27)<$ CS $(8.15)<\mathrm{RS}(8.37)<\mathrm{DS}$ (8.90; Table 1). Mean total $\mathrm{C}(\%)$ values were also different among all 4 bedding

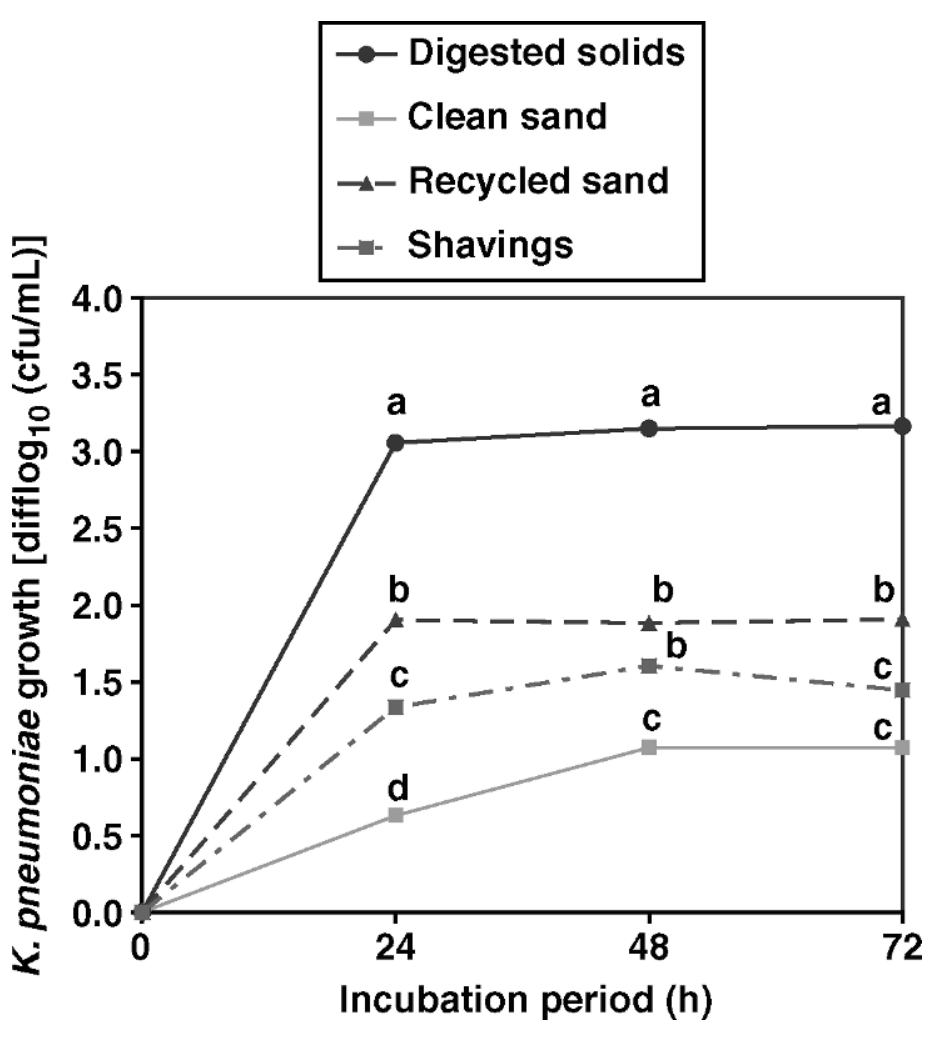

Figure 1. Comparison of growth of Klebsiella pneumoniae among bedding types at each time point. ${ }^{\mathrm{a}-\mathrm{d}}$ Different letters indicate a difference across bedding types at each time point $(P<0.05)$. 


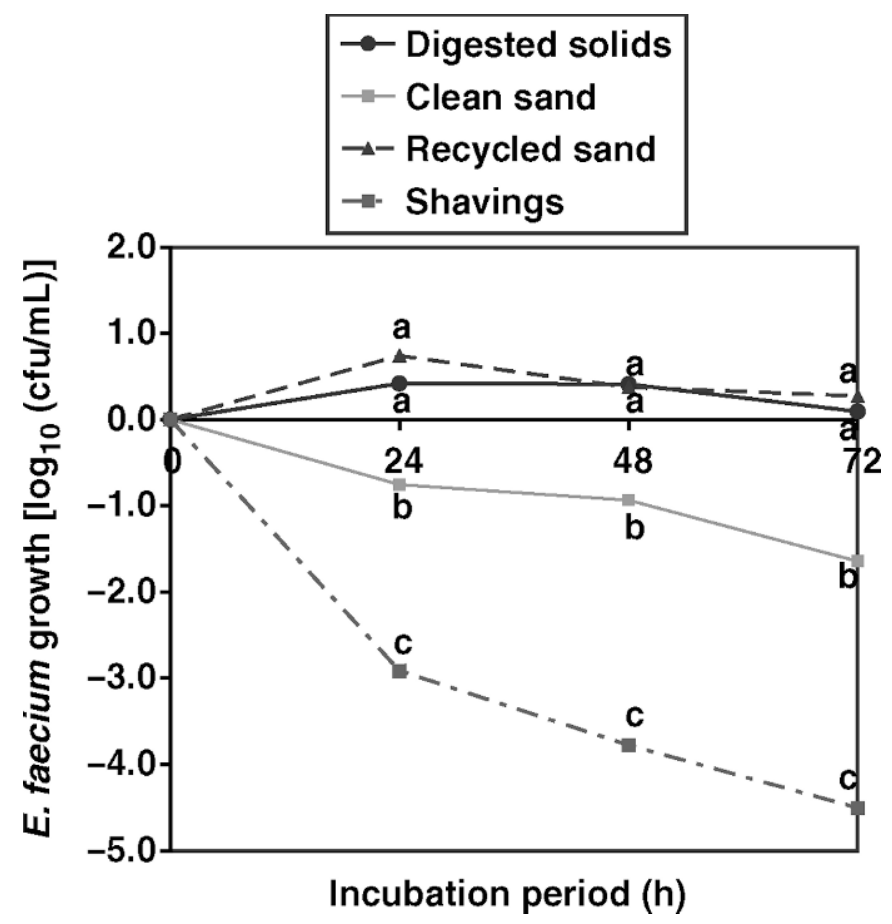

Figure 2. Comparison of growth of Enterococcus faecium among bedding types at each time point. ${ }^{a-c}$ Different letters indicate a difference across bedding types at each time point $(P<0.05)$.

types, ranging from lowest to highest as CS $(0.28 \%)<$ RS $(1.13 \%)<\mathrm{DS}(46.22 \%)<\mathrm{SH}(53.02 \%)$. Mean total $\mathrm{N}(\%)$ values were numerically low in all 4 bedding materials, with no difference between CS $(0.01 \%)$ and RS $(0.04 \%)$. Total N (\%) levels were higher for SH $(0.35 \%)$ and DS (1.99\%; Table 1$)$.

\section{Relationship Between Bedding Type and Bacterial Growth}

Positive growth of $K$. pneumoniae occurred within all bedding types studied. However, there were dramatic differences in the amount of growth observed among the 4 bedding types over the 72 -h incubation period. When ranked from least to most amount of growth of $K$. pneumoniae, the order was as follows: $\mathrm{CS}<\mathrm{SH}<\mathrm{RS}$ $<$ DS (Table 1, Figure 1).

Similarly, a relatively small amount of growth of $E$. faecium was observed for DS and RS. However, this growth was greater than growth of $E$. faecium for CS or SH (Table 1, Figure 2). Numbers of $E$. faecium declined dramatically over time for both SH and CS. The magnitude of this decline was greater for SH than CS (Table 1, Figure 2).

\section{Relationship Between Biochemical and Nutritional Properties of Different Bedding Materials and Bacterial Growth}

Univariate analysis indicated that bedding $\mathrm{pH}, \mathrm{C}(\%)$ content, and $\mathrm{N}(\%)$ content each were positively associated with growth of $K$. pneumoniae (Table 2). However, when all 3 variables were considered together in a multivariate model, only $\mathrm{pH}$ and $\mathrm{C}(\%)$ content remained as having a significant (positive) relationship with growth of $K$. pneumoniae (Table 2). Finally, when a variable describing bedding material $(\mathrm{CS}, \mathrm{RS}$, DS, or $\mathrm{SH})$ was forced into this final model, neither $\mathrm{pH}$ nor $\mathrm{C}$ (\%) content remained as significant. This suggests that high $\mathrm{pH}$ (e.g., as for DS or RS) and high $\mathrm{C}(\%)$ content (e.g., as for DS and SH) may both contribute, in part, to explain why some bedding materials supported moderate to high levels of growth of $K$. pneumoniae. However, $\mathrm{pH}$ cannot be the sole determinant for whether bedding supports growth of Klebsiella, because CS had a high $\mathrm{pH}$ but did not support growth of Klebsiella. Although these analyses were performed separately for each incubation period ( 0 to 24,0 to 48 , and 0 to 72), the estimates of the coefficients, their standard errors, and level of significance were numerically very similar for analyses from all 3 incubation periods. As such, only the results from the 0 to 72 -h incubation period analyses are reported (Table 2 ).

To further investigate the relationship between bacterial growth and biochemical property, we examined the relationship between the dependent variable (growth of $K$. pneumoniae) and each of the explanatory variables of interest $(\mathrm{pH}$, total $\mathrm{N} \%$, total $\mathrm{C} \%)$ within each of the 4 bedding types. In this analysis, none of the variables describing biochemical properties were associated with growth of $K$. pneumoniae within any of the 4 bedding types (results not shown).

Univariate analysis showed that bedding $\mathrm{pH}$ was positively associated and total $\mathrm{C}(\%)$ content was negatively associated with growth of $E$. faecium, respectively. However, when both these variables were considered together in a multivariate model, only $\mathrm{pH}$ had a significant (positive) relationship with growth of $E$. faecium (Table 2). Finally, when a variable describing bedding material (CS, RS, DS, or SH) was forced into this final model, even $\mathrm{pH}$ was no longer significant. These results suggest that the high $\mathrm{pH}$ of some of the bedding materials studied (e.g., as for DS and RS) may be, at least in part, an explanation for why some bedding materials supported growth of $E$. faecium. However, $\mathrm{pH}$ cannot be the only determinant for whether a bedding material supports growth of $E$. faecium, because CS also had a high $\mathrm{pH}$ but did not support growth of $E$. faecium. 
Table 2. Results of ANOVA describing the relationship between biochemical and nutrient properties of bedding and bacterial growth after incubation for $72 \mathrm{~h}^{1}$

\begin{tabular}{lccccc}
\hline & \multicolumn{2}{c}{ Growth of Enterococcus faecium } & & \multicolumn{2}{c}{ Growth of Klebsiella pneumoniae } \\
\cline { 2 - 2 } Model and covariates & Estimate (SE) & $P$-value & & Estimate (SE) & $P$-value \\
\hline Univariate models & & & & \\
pH & $0.91(0.14)$ & $<0.0001$ & & $0.18(0.07)$ & 0.018 \\
Total N (\%) & $0.61(0.39)$ & 0.12 & & $0.85(0.12)$ & $<0.0001$ \\
Total C (\%) & $-0.03(0.01)$ & 0.018 & & $0.017(0.005)$ & 0.0015 \\
Final (multivariate) model ${ }^{2}$ & & & & $0.40(0.064)$ & $<0.0001$ \\
pH & $0.91(0.14)$ & $<0.0001$ & & NS - removed & \\
Total N (\%) & NS - removed & & & $0.032(0.005)$ & $<0.0001$ \\
Total C (\%) & NS - removed & &
\end{tabular}

\footnotetext{
${ }^{1}$ Models shown are not adjusted for bedding type. Dependent variable $=$ bacterial growth $=$ difference $\left[\log _{10}(\mathrm{cfu} / \mathrm{mL}]\right.$ from 0 to $72 \mathrm{~h}$.

${ }^{2}$ When adjusted for bedding type in the final (multivariate) model, covariates describing $\mathrm{pH}$, total $\mathrm{N}$, and total $\mathrm{C}$ are no longer significant.
}

To further investigate this, we examined the relationship between each of the dependent variables of interest (growth of $E$. faecium) and each of the explanatory variables of interest [pH, total $\mathrm{N}(\%)$, total $\mathrm{C}(\%)]$ within each of the 4 bedding types. In this analysis, none of the variables describing biochemical properties were significantly associated with growth of $E$. faecium within each of the 4 bedding materials studied (results not shown).

\section{DISCUSSION}

The study design used allowed for a direct comparison of the inherent ability of 4 different bedding materials, $\mathrm{CS}, \mathrm{RS}, \mathrm{DS}$, and $\mathrm{SH}$, to reduce, sustain, or promote bacterial numbers under the stated conditions, independent of presence of feces, urine, or other contamination. Although the magnitude and variation of bacterial growth would be expected to vary from these results if the study had been conducted in an on-farm environment, due to variation in influencing factors such as ambient temperature, humidity, and bacterial inoculation dose, the presence of other growth-promoting or inhibitory substances such as leaking milk, feces, urine, or agonistic or antagonistic relationships with other bacterial species (Dodd et al., 1984), the relative ranking of the bacterial growth promoting ability of these bedding materials would very likely remain the same. Also, it would be challenging to design a study directly comparing these 4 bedding materials in an on-farm experiment while properly controlling for the many aforementioned influencing factors that would surely differ among different herds.

Klebsiella pneumoniae and E. faecium were selected to represent 2 large general families of environmental bacteria, the coliforms and environmental streptococci, respectively. Although E. faecium is not itself a mastitis pathogen, Enterococcus is a genus that contains fecal streptococci. It is recognized that some other species of bacteria within these 2 family groups could potentially have different growth requirements. By collecting unique bedding samples from many different farms, we were able to describe some of the variation in bacterial growth and biochemical properties within given bedding types.

\section{Ability of Bedding Materials to Support Growth of K. pneumoniae}

All 4 bedding materials evaluated allowed some mild, moderate, or marked increase in numbers of $K$. pneumoniae. The magnitude of growth was least in CS, followed by $\mathrm{SH}$, then RS, and highest in DS. High bedding $\mathrm{pH}$ and total $\mathrm{C}(\%)$ content were associated with increased growth of $K$. pneumoniae, which may explain, in part, why the lowest amount of growth of this species was observed in CS, which had the lowest levels of total $\mathrm{C}(\%)$ of the 4 bedding materials studied. The secondleast amount of growth of this species was observed in $\mathrm{SH}$, which had the lowest $\mathrm{pH}$ of the 4 bedding materials studied. The greatest amount of growth of this species was observed in DS, which had the highest $\mathrm{pH}$ and the second-highest total $\mathrm{C}$ (\%) content of the 4 bedding materials studied.

These results are generally consistent with a similarly designed study in which recycled manure promoted the most growth of $K$. pneumonia but with hardwood shavings also exhibiting positive growth (although softwood shavings reduced numbers of $K$. pneumoniae; Zehner et al., 1986). The current study did not differentiate between hardwood and softwood as the source of shavings. These results are also consistent with 1 field study that reported increased counts of coliforms and Klebsiella spp. after $1 \mathrm{~d}$ in herds using 
either CS or RS (Kristula et al., 2005) and with a second field study that reported bedding coliform and Klebsiella spp. counts as more numerous in sawdust vs. sand (Zdanowicz et al., 2004).

Recycled sand and CS supported moderate and small amounts of growth of $K$. pneumoniae, respectively. The total $\mathrm{C}(\%)$ content and $\mathrm{pH}$ in $\mathrm{RS}$ (vs. CS) may have provided sufficient nutrients and an appropriate chemical environment to support this growth. Bernard et al. (2003) determined OM concentrations in CS and RS sand bedding to be 0.6 and $1.1 \%$, respectively. Kristula et al. (2005) also reported that RS had a higher OM and lower DM compared with CS. The results of the current study agree with some previous studies in which bacterial growth in RS was greater than for CS (Reneau et al., 2002; Bernard et al., 2003). However, Kristula et al. (2005) reported no differences between $\mathrm{CS}$ and RS. One possible explanation for differing findings in the latter study could be that the used bedding samples, collected out of stalls, could have been previously contaminated with enough OM (e.g., fecal material) to support more bacterial growth in CS than was observed in the current study.

\section{Ability of Bedding Materials to Support Growth of E. faecium}

To summarize the study results for $E$. faecium, only $\mathrm{RS}$ supported some mild increase (growth) of bacterial numbers, whereas DS experienced no change in counts over the 72-h incubation period. In stark contrast, counts of $E$. faecium in $\mathrm{CS}$ and $\mathrm{SH}$ declined dramatically over the 72-h incubation period, with the magnitude of decline being greatest for SH. These findings are consistent with a similarly designed early study in which either hardwood or softwood SH reduced counts of Strep. uberis, whereas recycled dried manure resulted in significant growth of this pathogen (Zehner et al., 1986), and with a field experiment that reported higher counts of Streptococcus spp. bacteria on teat ends of cows housed on sand compared with SH (Zdanowicz et al., 2004). However, other studies have reported increased (not decreased) streptococci counts during the first $24 \mathrm{~h}$ in SH (Hogan and Smith, 1997). Discrepancies among studies may be attributed to differences in types of streptococcal species cultured or differences in other factors (e.g., humidity, temperature, fecal contamination).

One possible explanation for the decrease in $E$. faecium counts observed in $\mathrm{SH}$ may be that $E$. faecium has unique growth requirements that would not allow its survival and replication in the low-pH environment, whereas $K$. pneumoniae not only survived but multiplied. Alternately, it is also possible that other nonmeasured characteristics of $\mathrm{SH}$, such as resin acids, terpenes, and phenolic compounds in softwood shavings, may have inhibited bacterial growth (Zehner et al., 1986; Reneau et al., 2002). Streptococci and enterococci are known to ferment sugars as an energy source and do not require oxygen for growth but have limited synthetic abilities (Stainer et al., 1976). By comparison, coliforms like Klebsiella and Escherichia coli are more versatile organisms able to obtain energy either by fermentation or respiration and are able to metabolize a variety of organic compounds including sugars, AA, organic acids, and some organic compounds (Burlingame and Chapman, 1983; Brock et al., 1984). When considering CS, perhaps this bedding material lacked sufficient nutrients [e.g., total C (\%)] to sustain organism replication, despite providing a high-pH environment, which resulted in a declining growth phase of $E$. faecium. By comparison, RS did support small amounts of growth of $E$. faecium. These results are partially consistent with findings of 1 field study that reported increased counts of Streptococcus spp. after $1 \mathrm{~d}$ in herds using RS (Kristula et al., 2005). However, the latter study also reported growth of Streptococcus spp., over one day, in CS. As previously stated, the latter study findings could be attributed to the fact that the used bedding samples, collected out of stalls, could have been previously contaminated with enough OM (e.g., fecal material) to support more bacterial growth in CS than was observed in the current study.

The relationships observed in this study between growth of $K$. pneumonia or E. faecium and biochemical properties such as total $\mathrm{C}(\%)$ content or $\mathrm{pH}$ could be either direct or indirect in nature. That is, it is possible that other unmeasured characteristics, themselves associated with the biochemical properties of a bedding material, may be truly responsible for causing some or all of the bacterial growth observed. The fact that the within-bedding type analysis showed no relationship between either $\mathrm{pH}$, total $\mathrm{C}$, or total $\mathrm{N}$ and growth of either $K$. pneumoniae or $E$. faecium does not help us to classify biochemical properties as either direct vs. indirect causes of bacteria growth. It could still be possible that these biochemical properties (within or across 1 or more bedding types) really do have a significant direct effect on bacterial growth but that there was insufficient sample size, insufficient within-bedding type variation, or both, of these properties for samples collected in the current study, thus preventing our detection of such relationships, should they truly exist.

\section{Implications of Study Results for Mastitis Control Programs}

Taken as a whole, this study was able to directly contrast and rank the relative inherent ability of differ- 
ent bedding materials to sustain or promote growth of environmental bacteria. Digested manure solids promoted the greatest amounts of growth of K. pneumoniae, followed by RS and then SH, whereas CS promoted the least. There would seem to be a tradeoff in selecting $\mathrm{SH}$ as a bedding material, because it supported moderate growth of $K$. pneumoniae but caused a rapid decline in the numbers of $E$. faecium. However, RS, CS, and DS each only supported relatively small amounts of growth of $E$. faecium, so the benefit of $\mathrm{SH}$ relative to other bedding materials is limited. Furthermore, Klebsiella is a major mastitis pathogen, whereas $E$. faecium is not.

These results may be valuable to producers who are selecting a bedding material for use in their herds. Such information would be most valuable if considered before dairy construction, if the choice of a certain bedding material required planning and installing a specific manure-handling system.

Alternately, for producers already working with a specific bedding material in preexisting facilities, by having a better understanding of its bacterial growthsupporting abilities, they might be able to adopt management strategies to reduce or minimize bacterial growth in stalls. For example, management factors that may help reduce the impact of DS on mastitis risk include proper stall design, maintaining adequate bedding in stalls, frequent stall grooming, excellent ventilation, avoiding overcrowding of cows, parlor hygiene, and in dry lot dairies, corral grooming (Smith and Hogan, 2006). Although these recommendations should be universally adopted, regardless of the bedding type in use, it may be even more critical that producers understand the importance of adopting these management practices if using DS, RS, or $\mathrm{SH}$ as a bedding material.

If biochemical properties of bedding material such as $\mathrm{pH}$, total $\mathrm{N}(\%)$, or total $\mathrm{C}(\%)$ content do have a direct effect on bacterial growth, then it may be possible to adopt technologies or techniques to manipulate the underlying biochemical properties of some bedding materials to reduce their ability to promote bacterial growth. For example, if total C (\%) content (or associated factors such as total OM content) promotes bacterial growth in $\mathrm{RS}$, then perhaps sand reclamation systems could be modified to more fully remove OM during the mechanical separation process. Similarly, if some bacteria species do not multiply well in low-pH environments, then strategies to reduce bedding $\mathrm{pH}$ (e.g., through use of acidifying bedding conditioners) could be beneficial (Hogan and Smith, 1997; Hogan et al., 1999, 2007). Unfortunately, the latter studies generally only showed that bedding conditioners were effective in reducing bacteria counts for approximately $1 \mathrm{~d}$. It would be desirable and far more likely to be cost-effective if products could be developed that were effective in stalls for a longer period of time. The cost-benefit of using bedding conditioners in preventing IMI from environmental mastitis pathogens will also need to be evaluated.

Further research is needed to better identify and describe the physical and biochemical properties of various bedding materials that sustain or promote bacterial growth. Further research is also needed to develop strategies or management tools to manipulate these factors with the goal of reducing bacterial numbers in bedding in stalls. Finally, studies are needed to describe, under conditions of natural exposure, the relationship between these bedding characteristics, bacteria counts in bedding, and risk for IMI with environmental mastitis pathogens in dairy cattle.

\section{CONCLUSIONS}

Digested manure solids promoted the greatest amounts of growth of $K$. pneumoniae, followed by RS and then SH, whereas CS promoted the least. There would seem to be a tradeoff in selecting $\mathrm{SH}$ as a bedding material, because it supported moderate growth of $K$. pneumoniae but caused a rapid decline in the numbers of $E$. faecium. However, RS, CS, and DS each only supported relatively small amounts of growth of $E$. faecium, so the benefit of SH relative to other bedding materials is limited. High bedding $\mathrm{pH}$ may partially explain why some bedding materials supported growth of $E$. faecium (e.g., DS and RS). Both high bedding $\mathrm{pH}$ (e.g., as for DS or RS) and high total C (\%) content (e.g., as for DS and $\mathrm{SH}$ ) may partially explain why some bedding materials supported growth of $K$. pneumoniae.

\section{ACKNOWLEDGMENTS}

We would like to thank the dairies that contributed bedding samples for this study. Thanks also go to Eric Donley, Michelle Lucio, Roberta Kopel, Bev ByBee, and Karen Sheedy (Univ. Minnesota, St. Paul) for their laboratory and technical support with this study. Funding was provided by the University of Minnesota Laboratory for Udder Health, Minnesota Veterinary Diagnostic Laboratory (St. Paul).

\section{REFERENCES}

Bernard, J. K., D. R. Bray, and J. W. West. 2003. Bacterial concentrations and sand usage in free stalls bedded with fresh or recycled sand. Pages 153-161 in Natl. Mastitis Counc. Red. Meet. Proc., Fort Worth, TX. Natl. Mastitis Counc. Inc., Arlington, VA.

Bey, R. F., and J. K. Reneau. 2002. Manage bedding to control bacteria and reduce udder infections. Pages 103-113 in Proc. Minn. Dairy Health Conf. Coll. Vet. Med., Univ. Minnesota, St. Paul.

Brock, T. D., D. W. Smith, and M. T. Madigan. 1984. Biology of Microorganisms. 4th ed. Prentice-Hall Inc., Englewood Cliffs, NJ. 
Burlingame, B. L., and P. J. Chapman. 1983. Catabolism of phenylpropionic acid and its 3-hydroxy derivative by Escherichia coli. J. Bacteriol. 155:113-121.

Dodd, F. H., T. M. Higgs, and A. J. Bramley. 1984. Cubicle management and coliform mastitis. Vet. Rec. 114:522-523.

Eberhart, R. J. 1984. Coliform mastitis. In Symposium on Bovine Mastitis. Vet. Clin. North Am. Large Anim. Pract. 6:287-300.

Eckes, V., M. LaValle, R. F. Bey, R. J. Farnsworth, and J. K. Reneau. 2001. Environmental mastitis pathogens in fresh bedding material. Pages 183-184 in Proc. Natl. Mastitis Counc. Reg. Meet. Proc., Reno, NV. Natl. Mastitis Counc. Inc., Arlington, VA.

Fetrow, J., S. Stewart, S. Eicker, R. J. Farnsworth, and R. F. Bey. 2002. Mastitis: An economic consideration. Pages 3-47 in Proc. Natl. Mastitis Counc. Reg. Meet. Proc., Atlanta, GA. Natl. Mastitis Counc. Inc., Arlington, VA.

Gooch, C. A., J. S. Hogan, N. Glazier, and R. Noble. 2006. Use of post-digested separated manure solids as freestall bedding: A case study. Pages 151-160 in Proc. Annu. Meet. Natl. Mastitis Counc., Tampa, FL.

Hogan, J. S., V. L. Bagacz, L. M. Thompson, S. Romag, P. S. Schoenberger, W. P. Weiss, and K. L. Smith. 1999. Bacterial counts in sawdust and recycled manure bedding treated with commercial conditioners. J. Dairy Sci. 82:1690-1695.

Hogan, J. S., and K. L. Smith. 1987. A practical look at environmental mastitis. Compend. Cont. Educ. Pract. Vet. 9:F342.

Hogan, J., and L. Smith. 1997. Bacteria counts in sawdust bedding. J. Dairy Sci. 80:1600-1605

Hogan, J. S., K. L. Smith, K. H. Hoblet, D. A. Todhunter, P. S. Schoenberger, W. D. Hueston, D. E. Pritchard, G. L. Bowman, L. E. Heider, B. L. Brockett, and H. R. Conrad. 1989. Bacterial counts in bedding materials used on nine commercial dairies. J. Dairy Sci. 72:250-258.
Hogan, J. S., K. L. Smith, D. A. Todhunter, and P. S. Schoenberger. 1990. Bacterial counts associated with recycled newspaper bedding. J. Dairy Sci. 73:1756-1761.

Hogan, J. S., S. L. Wolf, and C. S. Petersson-Wolfe. 2007. Bacterial counts in organic materials used as free-stall bedding following treatment with a commercial conditioner. J. Dairy Sci. 90:1058-1062.

Johnson, A. 2001. Manure contamination of a dairy cow's feet and legs. Pages 11-13 in Proc. Minn. Dairy Health Conf. Coll. Vet. Med., Univ. Minnesota, St. Paul.

Kristula, M. A., W. Rogers, J. S. Hogan, and M. Sabo. 2005. Comparison of bacteria populations in clean and recycled sand used for bedding in dairy facilities. 88:4317-4325.

Rendos, J. J., R. J. Eberhart, and E. M. Kesler. 1975. Microbial populations of teat ends of dairy cows and bedding materials. J. Dairy Sci. 58:1492-1500.

Reneau, J. K., R. F. Bey, and R. J. Farnsworth. 2002. Bedding management and udder health. Pages 83-90 in Proc. Conv. Am. Assoc. Bovine Pract., Madison, WI. Am. Assoc. Bovine Pract., Rome, GA.

Smith, K. L., and J. S. Hogan. 2006. Bedding counts in manure solids. Pages 161-167 in Proc. Annu. Meet. Natl. Mastitis Counc., Tampa, FL.

Stainer, R. Y., E. A. Adelberg, and J. L. Ingraham. 1976. The Microbial World. 4th ed. Prentice-Hall Inc., Englewood cliffs, NJ.

Zdanowicz, M., J. A. Shelford, C. B. Tucker, D. M. Weary, and M. A. G. von Keyserlingk. 2004. Bacterial populations on teat ends of dairy cows housed in free stalls and bedded with either sand or sawdust. J. Dairy Sci. 87:1694-1701.

Zehner, M. M., R. J. Farnsworth, R. D. Appleman, K. Larntz, and J. A. Springer. 1986. Growth of environmental mastitis pathogens in various bedding materials. J. Dairy Sci. 69:1932-1941. 